\title{
Bioactive Compounds of the Volatile Oil of Dracocephalum kotschyi
}

Soodabeh Saeidnia ${ }^{\mathrm{a}, *}$, Ahmad Reza Goharia ${ }^{\mathrm{a}}$, Abbas Hadjiakhoondi ${ }^{\mathrm{b}}$, and Abbas Shafiee ${ }^{\mathrm{c}}$

a Medicinal Plants Research Center, Faculty of Pharmacy, Medical Sciences/University of Tehran, P. O. Box 14155-6451, Tehran, Iran. Fax: +98-21-66461178.

E-mail: soodabehsaeidnia@hotmail.com

b Department of Pharmacognosy, Faculty of Pharmacy, Tehran University of Medical Sciences, Tehran, Iran

c Department of Medicinal Chemistry, Faculty of Pharmacy, Tehran University of Medical Sciences, Tehran, Iran

* Author for correspondence and reprint requests

Z. Naturforsch. 62c, 793-796 (2007); received January 2/May 21, 2007

Trypanocidal activity was found in the volatile oil of dried Dracocephalum kotschyi. GCMS analysis determined that the major constituents of the oil were geranial $(35.8 \%)$, $\mathrm{C}_{10} \mathrm{H}_{14} \mathrm{O}(26.6 \%)$, limonene (15.8\%) and 1,1-dimethoxy decane (14.5\%). In order to isolate the unknown biologically active monoterpene, fractionation of the volatile oil was carried out by silica gel column chromatography. The structure of the oxygenated compound was confirmed to be limonene-10-al $\left(\mathrm{C}_{10} \mathrm{H}_{14} \mathrm{O}\right)$ by analysis of physical and spectroscopic data $\left({ }^{1} \mathrm{H}\right.$ NMR, ${ }^{13} \mathrm{C}$ NMR, HMBC and HMQC).

Key words: Dracocephalum kotschyi, Essential Oil, Oxygenated Monoterpene

\section{Introduction}

The name "badrashbi" has been applied to several species of Dracocephalum (Labiatae) in Iran (Mirheydar, 1995). The nature of terpenes within the secretory organs of leaves in this genus is different. Three groups of Dracocephalum are distinguished. The first goup (e.g. D. grandiflorum, $D$. nutans, D. scrobiculatum) is characterized by an abundance of sesquiterpenes and a much smaller quantity of monoterpenes. The second group (e.g. $D$. nodulsum) produces essentially monoterpenes. The species of the third group (e.g. D. feotidum, D. heterophyllum, D. moldavca) contain only monoterpenes oxygenated at the second carbon atom (Telepova et al., 1992). Also there are some oxygenated monoterpenes in the oil of Dracocephalum which could not be identified by GC-MS analysis (Holm et al., 1988).

Dracocephalum kotschyi Boiss. is an herbaceous plant endemic in Iran and its oil has been used in folk medicine as an antispasmodic agent (Rechinger, 1986; Zargari, 2000). There are a few reports on the chemical composition of the oil of D. kotschyi, which document considerable amounts of oxygenated monoterpenes (Golshani et al., 2004; Yaghmai and Tafazzoli, 1988). No literature review shows the presence of limonene-10-al in the oil of D. kotschyi, although we identified this compound in the ethyl acetate extract of $D$. kotschyi and $D$. subcapitatum as the main trypanocidal compound (Saeidnia et al., 2004, 2005).

In this study we analyzed the essential oil of $D$. kotschyi (originated from Alborz Mountains) and detected the oxygenated monoterpenes, especially limonene-10-al, based on the trypanocidal assay of the oil against epimastigotes of Trypanosoma cruzi, the causative agent of Chagas disease.

\section{Experimental}

\section{General}

GC-MS analysis was carried out by a HP 6890 (Hewlett Packard) instrument including a quadrupole detector $(70 \mathrm{eV})$; split ratio 1:20; carrier gas $\mathrm{N}_{2}$; flow rate $0.8 \mathrm{~mL} / \mathrm{min}$; temperature program: $60{ }^{\circ} \mathrm{C}$ for $2 \mathrm{~min}, 5^{\circ} \mathrm{C} / \mathrm{min}$ to $240^{\circ} \mathrm{C}$; injector temperature $260{ }^{\circ} \mathrm{C}$; detector temperature $230{ }^{\circ} \mathrm{C}$. Capillary column was HP-5MS $(30 \mathrm{~m} \times 0.25 \mathrm{~mm}$ i. d., film thickness $0.25 \mu \mathrm{m})$. Injection volume was $1 \mu \mathrm{L} .{ }^{1} \mathrm{H}$ and ${ }^{13} \mathrm{C}$ NMR spectra were measured on a JEOL JNM-LA500 $\left(500 \mathrm{MHz}\right.$ for ${ }^{1} \mathrm{H}$ and 125 $\mathrm{MHz}$ for ${ }^{13} \mathrm{C}$ ) spectrometer with TMS as internal standard, and chemical shifts are given in $\delta(\mathrm{ppm})$. Silica gel $60 \mathrm{~F}_{254}$ pre-coated plates (Merck) were used for TLC. The spots were visualized by spray- 
ing with anisaldehyde- $\mathrm{H}_{2} \mathrm{SO}_{4}$ reagent followed by heating.

\section{Plant material}

Aerial parts of D. kotschyi were collected from Tochal Mountain near to Tehran during the flowering stage in July 2002. The altitude was $c a$. $3200 \mathrm{~m}$ above sea level. A voucher specimen was deposited at the Herbarium of Faculty of Pharmacy, Mazandaran University of Medical Sciences, Sari, Iran.

\section{Oil extraction and GC-MS analysis}

The volatile oil was obtained from $1 \mathrm{~kg}$ of aerial plant parts by hydrodistillation in a Clevenger type apparatus for $3 \mathrm{~h}$. The mean yield of the extraction was $0.6 \% \mathrm{v} / \mathrm{w}$ based on the dry weight of the sample. The yellow oil of the plant was dried over dry sodium sulfate. Confirmation of compound identities was carried out comparing the retention times of $n$-alkanes $\left(\mathrm{C}_{8}-\mathrm{C}_{25}\right)$, which were injected before the oil under the same conditions. Identification of the oil constituents was based on the comparison of their MS spectra and RI values with those reported in the literature (Adams, 1994).

\section{Isolation of the main terpenes}

The essential oil ( $4 \mathrm{~g})$ was submitted to silica gel column chromatography with hexane/ $\mathrm{CHCl}_{3}(1: 1$, $0: 1 \mathrm{v} / \mathrm{v}$ ) and EtOAc as eluents to give four fractions (A-D). Fraction B was compound $\mathbf{1}(90 \mathrm{mg})$. Fraction C $(1.5 \mathrm{~g})$ was fractionated with hexane/ EtOAc $(9: 1,1: 1 \mathrm{v} / \mathrm{v})$ and EtOAc as eluents in or- der to obtain three parts $(\mathrm{C} 1-\mathrm{C} 3)$. Fraction $\mathrm{C} 2$ (500 mg) was chromatographed twice with hexane/ EtOAc $(19: 1,0: 1 \mathrm{v} / \mathrm{v})$ to afford compound 2 (115 mg) and compound 3 (9 mg).

Limonene-10-al (1): Colourless oil, $[\alpha]_{\mathrm{D}}^{25}+88.0^{\circ}$ $\left(\mathrm{CHCl}_{3}, c\right.$ 0.003). - NMR data: Table I.

\section{In vitro evaluation of trypanocidal activity}

Epimastigotes of T. cruzi (Tulahuen strain, from Kyoto University, Japan) were kept in GIT medium (Wako Pure Chemical Industry, Ltd, Osaka, Japan) supplemented with hemin $(12.4 \mu \mathrm{M}$, Wako). The epimastigotes in GIT medium $(10 \mu \mathrm{L})$ were incubated with a test sample dissolved in $\mathrm{EtOH}$ $(5 \mu \mathrm{L})$ and autoclaved saline $(185 \mu \mathrm{L})$. All samples were incubated at $27^{\circ} \mathrm{C}$ for $24 \mathrm{~h}$. The movement of epimastigotes was observed under a microscope. We assumed that immobilized organisms were dead. The control contained ethanol in the same proportion as used to dissolve the drugs. Each assay was performed in duplicate. Minimum lethal concentration (MLC, concentration at which all epimastigotes were dead) of each compound was performed. Gentian violet $(\mathrm{MLC}=$ $6.3 \mu \mathrm{M}$ ) was used as a positive control (Kiuchi et al., 2002).

\section{Results and Discussion}

Dried aerial parts of D. kotschyi, collected in Iran, were extracted by hydrodistillation to obtain the volatile oil. The oil was yellow with pleasant and intense odour, which was dominated by a fresh citral smell. The oil showed strong in vitro trypanocidal activity against epimastigotes of $T$.

\begin{tabular}{|c|c|c|c|c|}
\hline \multirow[t]{2}{*}{$\mathrm{C}$} & \multicolumn{2}{|r|}{ HMQC } & \multirow[t]{2}{*}{ HMBC } & \multirow[t]{2}{*}{${ }^{1} \mathrm{H}-{ }^{1} \mathrm{H} \mathrm{COSY}$} \\
\hline & $\delta_{\mathrm{C}}$ & $\delta_{\mathrm{H}}$ & & \\
\hline 1 & 133.8 & & $3 \mathrm{H}-7$ & \\
\hline 2 & 120.0 & $5.41(1 \mathrm{H}, b r s)$ & $3 \mathrm{H}-7$ & $\mathrm{H}-3 \mathrm{~b}, 3 \mathrm{H}-7$ \\
\hline 3 & 30.6 & $\begin{array}{l}1.93(1 \mathrm{H}, m, \mathrm{H}-3 \mathrm{a}) \\
2.17(1 \mathrm{H}, m, \mathrm{H}-3 \mathrm{~b})\end{array}$ & & $\begin{array}{l}\mathrm{H}-3 \mathrm{~b} \\
\mathrm{H}-4, \mathrm{H}-3 \mathrm{a}, \mathrm{H}-2\end{array}$ \\
\hline 4 & 31.5 & $2.71(1 \mathrm{H}, m)$ & $\mathrm{H}-5 \mathrm{a}$ & $\mathrm{H}-3 \mathrm{a}, \mathrm{H}-5 \mathrm{a}$ \\
\hline 5 & 29.9 & $\begin{array}{l}1.52(1 \mathrm{H}, m, \mathrm{H}-5 \mathrm{a}) \\
1.78(1 \mathrm{H}, m, \mathrm{H}-5 \mathrm{~b})\end{array}$ & & $\begin{array}{l}\mathrm{H}-4,2 \mathrm{H}-6, \mathrm{H}-5 \mathrm{~b} \\
\mathrm{H}-5 \mathrm{a}\end{array}$ \\
\hline 6 & 27.6 & $1.89(2 \mathrm{H}, m)$ & $3 \mathrm{H}-7$ & $\mathrm{H}-5 \mathrm{a}$ \\
\hline 7 & 23.4 & $1.66(3 \mathrm{H}, s)$ & & $\mathrm{H}-2$ \\
\hline 8 & 154.7 & & $\mathrm{H}-9 \mathrm{a}, 2 \mathrm{H}-10$ & \\
\hline 9 & 132.9 & $\begin{array}{l}5.99(1 \mathrm{H}, s, \mathrm{H}-9 \mathrm{a}) \\
6.25(1 \mathrm{H}, s, \mathrm{H}-9 \mathrm{~b})\end{array}$ & & \\
\hline 10 & 194.6 & $9.54(1 \mathrm{H}, s)$ & $\mathrm{H}-9 \mathrm{a}$ & \\
\hline
\end{tabular}

Table I. NMR data of limonene-10-al (1).

\footnotetext{
a Recorded in $\mathrm{CDCl}_{3}$ at $500 \mathrm{MHz}\left({ }^{1} \mathrm{H}\right)$ and $125 \mathrm{MHz}\left({ }^{13} \mathrm{C}\right)$, respectively.
} 
Table II. Percentage composition of the volatile oil from Dracocephalum kotschyi.

\begin{tabular}{lcc}
\hline Compound & RI & Percentage in oil \\
\hline Limonene & 1031 & 15.8 \\
Geranial & 1270 & 35.8 \\
1,1-Dimethoxy decane & 1377 & 14.5 \\
$\mathrm{C}_{10} \mathrm{H}_{14} \mathrm{O}^{\mathrm{a}}$ & 1421 & 26.6 \\
$\mathrm{C}_{x} \mathrm{H}_{y}{ }^{\mathrm{b}}$ & & 30.3 \\
$\mathrm{C}_{x} \mathrm{H}_{y} \mathrm{O}_{z}{ }^{\mathrm{c}}$ & & 62.4 \\
Total & & 92.7 \\
Unidentified & & 7.3 \\
\hline
\end{tabular}

a This was in accordance with limonene-10-al.

b Monoterpene hydrocarbons.

c Oxygenated monoterpenes.

cruzi $(\mathrm{MLC}=6.2 \mu \mathrm{M})$. Four constituents were identified by GC-MS analysis representing $92.7 \%$ of the total oil (Table II). Comparison of the mass data and retention indices with references led to geranial $(35.8 \%)$, an oxygenated monoterpene $(26.6 \%)$, limonene $(15.8 \%)$ and 1,1-dimethoxy decane $(14.5 \%)$. In order to isolate the unknown oxygenated monoterpene, which represented more than one-fourth of the oil, fractionation of the volatile oil was carried out by silica gel column chromatography with hexane/ $\mathrm{CHCl}_{3}$ to afford four fractions (A-D). Trypanocidal activity of these fractions was tested. Fraction B (compound 1) showed strong trypanocidal activity (MLC = $3.1 \mu \mathrm{M}$ ) and produced only one shiny blue spot on a TLC plate with hexane/ $\mathrm{CHCl}_{3}(1: 1 \mathrm{v} / \mathrm{v})$ after treatment by anisaldehyde- $\mathrm{H}_{2} \mathrm{SO}_{4}$ reagent followed by heating. Compound $\mathbf{1}$ was identified by the analysis of its ${ }^{1} \mathrm{H},{ }^{13} \mathrm{C} \mathrm{NMR}, \mathrm{HMBC}$ and HMQC spectra as limonene-10-al (Table I). Although this is a known compound, its 2D-NMR data were not available in the literature. It is in accordance with the molecular formula $\mathrm{C}_{10} \mathrm{H}_{14} \mathrm{O}$,

Adams R. P. (1994), Identification of Essential Oil Components by Gas Chromatography/Mass Spectroscopy. Allured Publishing Corporation, Carol Stream, IL.

Bohlmann F., Zeisberg R., and Klein E. (1975), ${ }^{13} \mathrm{C}$ NMR Spektren von Monoterpenen. Org. Magn. Reson. 7, 426-432.

Duetz W. A., Bouwmeester H., and Van Beilen J. B. (2003), Biotransformation of limonene by bacteria, fungi, yeasts and plants. Appl. Microbiol. Biotechnol. 61, 269-277.

Golshani S., Karamkhani F., Monsef-Esfehani H. R., and Abdollahi M. (2004), Antinociceptive effects of the revealed by GC-MS. Further separation of the active fraction $\mathrm{C}$ by silica gel $\mathrm{CC}$ with hexane/ EtOAc led to the isolation of compounds $\mathbf{2}$ and $\mathbf{3}$. Comparison of their NMR spectra with those of reference data confirmed the structure of geranial and neral (Bohlmann et al., 1975), which showed strong activities, $\mathrm{MLC}=3.1 \mu \mathrm{M}$ for both compounds, against epimastigotes of T. cruzi.

A previous study on the volatile oil of $D$. kotschyi showed the antivisceral pain property due to the presence of limonene and terpineol (Golshani et al., 2004), also Yaghmai and Tafazzoli (1988) reported citral, myrcene, $\beta$-caryophyllene and terpinyl acetate as the main constituents of $D$. kotschyi from northeast mountains. Javidnia et al. (2005) reported the main components of the oil of $D$. kotschyi as $\alpha$-pinene, caryophyllene oxide, terpinen-4-ol and germacrene D. In the present study, the oil of D. kotschyi was enriched by oxygenated monoterpenes, representing $62.4 \%$ of the total oil. Limonene-10-al has been identified for the first time in the oil of this plant. The formation of limonene-derived compounds must have been catalyzed by an array of plant enzymes. C10 hydroxylation and its further conversion to an aldehyde has not been reported so far, but can be postulated to occur in D. feotidum and D. subcapitatum because these species contain limonene-10al (Duetz et al., 2003; Saeidnia et al., 2005). It seems that the trypanocidal active component of the oil, limonene-10-al, has not been reported until now because of different geographical habitats of the original plants or incomplete identification of the oil by using GC-MS.

\section{Acknowledgements}

This work was supported by a grant from Tehran University of Medical Sciences. essential oil of Dracocephalum kotschyi in the mouse writhing test. J. Pharm. Pharmaceut. Sci. 7, 76-79.

Holm Y., Hiltunen R., and Nykanen I. (1988), Capillary gas chromatographic-mass spectroscopic determination of the flavor composition of dragonhead Dracocephalum moldavica L. Flav. Frag. J. 3, 109-112.

Javidnia K., Miri R., Fahham N., and Mehregan I. (2005), Composition of the essential oil of Dracocephalum kotschyi Boiss. from Iran. J. Essent. Oil Res. 17, $481-482$.

Kiuchi F., Itano Y., Uchiyama N., Honda G., Tsubouchi A., Nakajima-Shimada J., and Aoki T. (2002), Mono- 
terpene hydroperoxides with trypanocidal activity from Chenopodium ambrosoides. J. Nat. Prod. 65, 509-512.

Mirheydar H. (1995), Maaref Giahi (Plant Knowledge). Daftare Nashre Farhange Eslami, Tehran, pp. 109111.

Rechinger K. H. (1986), Flora Iranica: Labiatae, Vol. 150. Akademische Druck- und Verlagsanstalt, Graz, pp. $218-230$.

Saeidnia S., Gohari A. R., Uchiyama N., Ito M., Honda G., and Kiuchi F. (2004), Two new monoterpene glycosides and trypanocidal terpenoids from Dracocephalum kotschyi. Chem. Pharm. Bull. 52, 1249-1250.
Saeidnia S., Gohari A. R., Ito M., Kiuchi F., and Honda G. (2005), Bioactive constituents from Dracocephalum subcapitatum (O. Kuntze) Lipsky. Z. Naturforsch. 60c, $22-24$.

Telepova N. M., Budantzev L. A., and Shavarda L. A. (1992), A comparative study of nature of terpenes within the secretory organs of leaves in some species of Dracocephalum (Labiatae). Bull. Soc. Bot. France Lett. Bot. 139, 247- 264.

Yaghmai M. S. and Tafazzoli R. (1988), The essential oil of Dracocephalum kotschyi Boiss. Flav. Frag. J. 3, $33-36$.

Zargari A. (2000), Medicinal Plants, Vol. 4. Tehran University Publication, Tehran, pp. $82-83$. 